\title{
Systematic Review of Medicinal Plants Used for Treatment of Diabetes in Human Clinical Trials: An ASEAN Perspective
}

\author{
Nazurah Hamizah Salleh, ${ }^{1}$ Ihsan Nazurah Zulkipli, ${ }^{1}$ Hartini Mohd Yasin, ${ }^{2}$ \\ Fairuzeta Ja'afar, ${ }^{2}$ Norhayati Ahmad, ${ }^{3,4}$ Wan Amir Nizam Wan Ahmad, \\ and Siti Rohaiza Ahmad ${ }^{1}$ \\ ${ }^{1}$ PAPRSB Institute of Health Sciences, Universiti Brunei Darussalam, Jalan Tungku Link, Gadong BE1410, Brunei Darussalam \\ ${ }^{2}$ Chemical Sciences, Faculty of Science, Universiti Brunei Darussalam, Jalan Tungku Link, Gadong BE1410, Brunei Darussalam \\ ${ }^{3}$ Environmental and Life Sciences, Faculty of Science, Universiti Brunei Darussalam, Jalan Tungku Link, Gadong BE1410, \\ Brunei Darussalam \\ ${ }^{4}$ Institute for Biodiversity and Environmental Research, Universiti Brunei Darussalam, Jalan Tungku Link, Gadong BE1410, \\ Brunei Darussalam \\ ${ }^{5}$ School of Health Sciences, University Sains Malaysia, Gelugor, Malaysia
}

Correspondence should be addressed to Siti Rohaiza Ahmad; rohaiza.ahmad@ubd.edu.bn

Received 27 January 2021; Revised 17 March 2021; Accepted 23 September 2021; Published 13 October 2021

Academic Editor: Armando Zarrelli

Copyright (c) 2021 Nazurah Hamizah Salleh et al. This is an open access article distributed under the Creative Commons Attribution License, which permits unrestricted use, distribution, and reproduction in any medium, provided the original work is properly cited.

\begin{abstract}
Traditionally, there are some medicinal plants believed to treat diabetes, as they have been proven in research studies to possess antidiabetic properties, such as improved insulin sensitivity and hypoglycemic activities, due to their high level of phenolic compounds, flavonoids, terpenoids, alkaloids, and glycosides. We conducted a systematic review to identify potential medicinal plants used during human clinical trials in the Association of Southeast Asian Nation (ASEAN) countries on prediabetic or type 2 diabetic individuals and to potentially identify any bioactive compounds involved in effectively treating symptoms of diabetes such as lowering of blood glucose. A total of 1209 reference titles were retrieved from four selected databases (Science Direct, Scopus, Springer Link, and PubMed) and only three met the inclusion criteria. Upon evaluation of the selected articles, four medicinal plants were identified: turmeric (Curcuma longa), garlic (Allium sativum L.), bitter melon (Momordica charantia), and Rosella flower (Hibiscus sabdariffa L.). Of these, only the bitter melon study did not show any significant change in the blood glucose of participants after intervention. This review demonstrates the limitations in published articles of human clinical trials for medicinal plants' intervention for diabetes. Upon further investigations on the four identified medicinal plants included in the animal studies, the findings showed positive effects in the management of diabetes, such as hyperglycemia. Hence, further testing and standardization of the methods in the studies can be suggested for human clinical trials for reliable data collections such as methods of extract preparation, duration of intervention, and conditions set for the study design.
\end{abstract}

\section{Introduction}

Diabetes mellitus (DM) is increasingly prevalent and continues to be a leading health burden worldwide, with consistent increases in mortality due to the various complications associated with the disease, such as coronary heart disease, nephropathy, and neurodegeneration. Although diagnosis and management of the disease have improved considerably; according to the World Health Organization (WHO), the lack of resources, specialized services, and skilled health workers in Southeast Asian countries contribute to the steady rise of the diabetes epidemic, especially type $2 \mathrm{DM}$ in adults [1]. Hence, there is a need to develop low-cost solutions for diabetes, especially in underserved areas in different regions [1]. 
With increasing global expenditure on diabetes of over USD 700 billion (10\%) [2] and the adverse effects of prolonged consumption of conventional drugs [3], natural and less invasive products are gaining popularity for prevention and as therapeutic measures. Some natural products have been shown to effectively control the abnormality in carbohydrate metabolism, further reducing the deterioration of overall health of affected individuals; have also shown to be relatively low in cost; and have minimal to no side effects at all $[4,5]$.

Traditionally, it is known plants naturally contain healing properties for various ailments, have been used for generations, and play an important role in leading modern medicine to where it is now. Generations worth of knowledge provide invaluable insights into understanding the various uses of different medicinal plants in different cultures around the world and have assisted researchers in identifying potencies of these plants to cure diseases [6-8].

By the early nineteenth century, centuries of passed down knowledge on the traditional uses of plants and the methods of herbal preparation were better understood as apothecaries were able to isolate bioactive compounds, mainly alkaloids such as quinine, caffeine, and cocaine from their natural sources, which gradually have shifted to synthetic development of these phytochemicals for better efficiency and potency [9, 10], whereby, for the latter, some known drugs are aspirin from willow bark, steroids from Mexican yam, and opium from poppy $[9,11]$. Although the cost is lowered as opposed to isolating compounds from natural sources, over time they have shown side effects that could potentially harm consumers [7].

There are some medicinal plants believed to treat diabetes, and scientific studies have reported certain medicinal plants do contain antidiabetic properties, such as improved insulin sensitivity and hypoglycemic activities [12]. This is often associated with their high level of phenolic compounds, flavonoids, terpenoids, alkaloids, and glycosides, which can improve insulin secretions as well as control blood glucose [13]. Atanasov et al. [9] reported that some of the compounds known to have beneficial effects on carbohydrate metabolism are quercetin and resveratrol, which are found in onion (Allium cepa L.) and grapevine (Vitis vinifera L.), respectively.

In 2017, the Association of Southeast Asian Nation (ASEAN) secretariat published an updated compilation of available medicinal plants for the 10 ASEAN countries, except for Singapore and Vietnam, which reported various health benefits of these plants such as treatment for inflammation, hemorrhoids, and diabetes [14]. Although the plants' chemical constituents, medical uses, and traditional practices were mentioned, most remain unsupported, or clinical evidence is still limited or unavailable to support this information and health claims.

The preclinical studies that were already conducted on some of these plants were notably done mostly on animals rather than on humans. Therefore, this study will attempt to investigate existing human clinical studies conducted in Southeast Asian countries, to identify medicinal plants that have proven to be beneficial for the management of type 2 diabetes mellitus, particularly in lowering blood glucose.

The study objective is to conduct a systematic review of published research conducted on medicinal plants in human studies in ASEAN countries on prediabetic or type 2 diabetic patients and to eventually identify bioactive compounds of these medicinal plants that contribute to the effectiveness in treating diabetes.

\section{Material and Methods}

2.1. Literature Research. To assess findings on clinical evidence in different ASEAN countries on the usage of medicinal plants that have shown some form of antidiabetic effects in human studies, an extensive literature search has been conducted and completed using multiple databases (Science Direct, Scopus, Springer Link, and PubMed) covering all published journals from the 1900s to the most current.

Key search items used in this study included, "diabet** OR “type 2 diabetes mellitus" OR “pre-diabet**”, “ASEAN OR Brunei OR Indonesia OR Laos OR Malaysia OR Philippines OR Thailand OR Vietnam OR Myanmar OR Singapore OR Cambodia", "medicinal plant” OR "medicinal herb" OR "herbal".

We have limited our search to focus on medicinal plants in ASEAN countries and human clinical studies, whereby only original research papers with completed clinical trials and assessment are considered. Mendeley 1.19.4 was used as a database manager.

2.2. Study Inclusion. Using the PRISMA diagram as guidance (Figure 1) which includes identifying and screening of articles from databases, relevant articles were selected based on identified medicinal plants believed to be antidiabetic in their respective countries in which these plants have been used as an intervention on prediabetic or type 2 diabetic participants in ASEAN countries and assessed outcome measures related to the management of type $2 \mathrm{DM}$ such as lowering of blood glucose amongst participants upon completion of the intervention in varying timeframes.

Two independent reviewers evaluated all reference titles obtained from all selected databases. Then, abstracts were used as guidance by the two reviewers to assess and determine whether the articles met the selection criteria for the full review. Any discrepancies with the selected articles were settled by having a third independent reviewer reach a consensus.

2.3. Data Extraction. Data extracted from each study include title, author(s), journal, year and country of publication, study characteristics (study design, study duration), characteristics of participants (gender, age, sample size), plant type and extractions, intervention (type of treatment) and control used, number of dropouts, methods, and results from the studies. These studies are summarized in Table 1. 


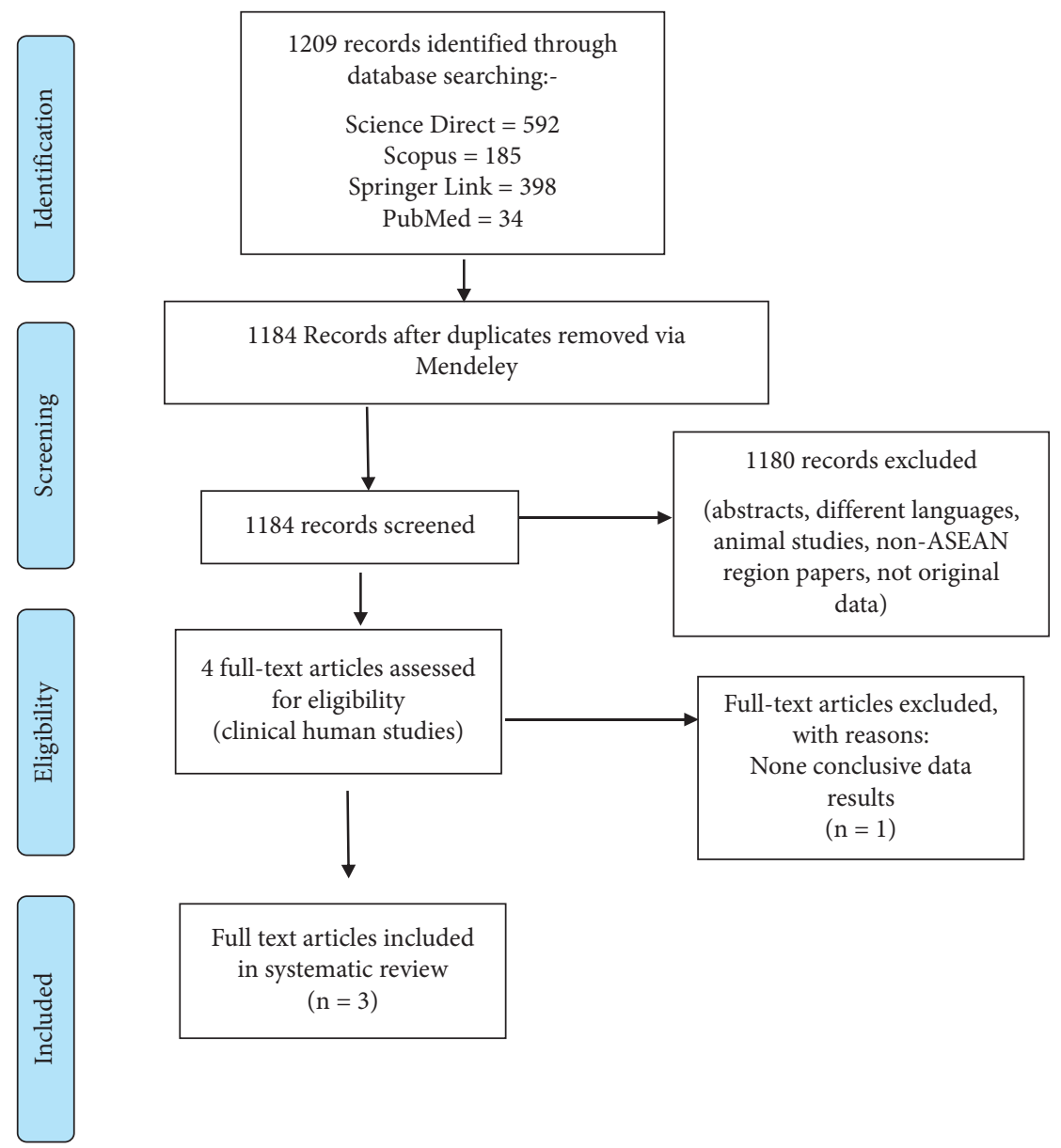

FIGURE 1: PRISMA flow diagram of study selection of initial and updated literature searches (inclusion and exclusion) for the systematic review.

2.4. Methodological Quality Assessment. Final identified studies were assigned to three reviewers, whereby two reviewers have independently completed data extraction and assessed the quality of studies using the Downs and Black quality assessment tool, which is a well-used and validated numerical rating scale for assessment of the methodological quality of both randomized and nonrandomized studies [15]. The 27 criteria of the Downs and Black assessment tool can be used for both randomized and nonrandomized studies and assesses study reporting (10 items), external validity, that is, the representativeness of findings based on the study population ( 3 items), and internal validity (14 items) which include bias and power, with a maximum scoring of 32 points.

\section{Results}

A total of 1209 reference titles were identified from the literature search of the four mentioned selected databases. Using Mendeley as the database manager, these underwent further screening to remove any duplicates $(n=25)$. Two independent reviewers completed further screening, to remove nonrelevant articles that do not have full-text articles, articles of non-English language, and studies without human trials, including only ASEAN region papers and original data.
From the screening, only four articles were selected for full reviews; however, one article was eliminated as the study did not provide a conclusive outcome with measured data (Figure 1), of which, out of the three selected studies, two studies were randomized clinical trials.

\subsection{Comparison of Methodological Quality Using Downs and} Black Checklist. The three selected articles for full review underwent quality assessment using the Downs and Black tool, whereby, overall, the mean score was 18 , with a grade as being "fair" (14-18 points). One article scored the highest (22 points) and was graded as "good" (19-23 points), providing detailed study design and clear external and internal validities, while two other articles scored the same (16 points) and were graded as "fair" (14-18 points) (15).

3.2. Countries Included and Study Outcome. After the rigorous screening of literature searches for human clinical studies in ASEAN countries, only two Southeast Asian countries were included for review: the Philippines (1 study) and Indonesia (2 studies). Only the nonrandomized (quasiexperimental) study used a chosen medicinal plant, rosella flower (H. sabdariffa L.) in its natural form, as ready-todrink tea with an added natural sweetener, stevia. On the 
TABLE 1: Completed summary of all data extractions of selected published literature articles on human studies and medicinal plants in the management of type 2 diabetes mellitus in ASEAN countries.

\begin{tabular}{|c|c|c|c|c|c|}
\hline $\begin{array}{l}\text { Author(s), year } \\
\text { of publication, } \\
\text { study design }\end{array}$ & $\begin{array}{c}\text { Plant name and type } \\
\text { of extraction }\end{array}$ & $\begin{array}{l}\text { Country participant } \\
\text { description, no. of } \\
\text { dropouts }\end{array}$ & $\begin{array}{c}\text { Duration and type of } \\
\text { treatment }\end{array}$ & Study outcome & $\begin{array}{l}\text { Brief methods, e.g., } \\
\text { blood test }\end{array}$ \\
\hline $\begin{array}{l}\text { Mayasari et al., } \\
2018\end{array}$ & Rosella with stevia & Yogyakarta, Indonesia & 14-day treatment & Posttreatment & \multirow[b]{2}{*}{$\begin{array}{c}\text { Venous blood } \\
\text { samples collected } \\
\text { for FBG and 2-hour } \\
\text { PBG }\end{array}$} \\
\hline $\begin{array}{l}\text { Quasi- } \\
\text { experimental } \\
\text { research study }\end{array}$ & $\begin{array}{l}\text { Each rosella-stevia tea } \\
\text { bag is brewed with } \\
250 \mathrm{ml} \text { of boiling } \\
\text { water for } 5 \text { mins and } \\
\text { cooled down for } \\
20-30 \text { minutes before } \\
\text { consuming }\end{array}$ & $\begin{array}{l}2 \text { groups (control and } \\
\text { treatment group) }\end{array}$ & $\begin{array}{l}\text { (1) Fast for } 8 \text { hours the } \\
\text { night before the first } \\
\text { day of treatment, to } \\
\text { withdraw participants' } \\
\text { blood for fasting blood } \\
\text { glucose readings } \\
\text { (2) Each participant was } \\
\text { given } 75 \mathrm{~g} \text { sugar in } \\
250 \mathrm{ml} \text { water and rested } \\
\text { for } 2 \text { hours, for } 2^{\text {nd }} \\
\text { blood withdrawal as } 2- \\
\text { hour postprandial } \\
\text { blood glucose } \\
\text { (3) Treatment group }\end{array}$ & $\begin{array}{l}\text { Tea consumption } \\
\text { significantly lower } \\
\text { FBG level but not the } \\
\text { 2-hour PBG level }\end{array}$ & \\
\hline \multirow[t]{2}{*}{ Dans et al., 2007} & \multirow{2}{*}{$\begin{array}{l}\text { M. charantia (Bitter } \\
\text { melon) }\end{array}$} & \multirow{2}{*}{$\begin{array}{c}\text { Manila, Philippines } \\
40 \text { patients with newly } \\
\text { diagnosed or poorly } \\
\text { controlled type } 2 \\
\text { diabetes with A1c } \\
\text { levels between } 7 \% \text { and } \\
9 \%\end{array}$} & 3-month treatment: & \multirow{4}{*}{$\begin{array}{l}\text { No significant effect on } \\
\text { mean FBG, total } \\
\text { cholesterol, and weight } \\
\text { or on serum creatinine, } \\
\text { ALT, AST, sodium, } \\
\text { and potassium }\end{array}$} & Each monthly visit: \\
\hline & & & $\begin{array}{l}\text { (1) M. charantia } \\
\text { capsules or placebo: } \\
\text { (i) } 2 \text { capsules, } 3 \text { times } \\
\text { per day after meals for } 3 \\
\text { months }\end{array}$ & & $\begin{array}{l}\text { (i) Capillary blood } \\
\text { sugar levels } \\
\text { (ii) Interviewed on } \\
\text { compliance and } \\
\text { adverse events }\end{array}$ \\
\hline \multirow[t]{2}{*}{$\begin{array}{l}\text { Randomized } \\
\text { double-blind, } \\
\text { placebo- } \\
\text { controlled trial }\end{array}$} & \multirow[t]{2}{*}{$\begin{array}{c}\text { As charantia } \\
\text { ampalaya capsules vs. } \\
\text { placebo capsules }\end{array}$} & & & & $\begin{array}{l}\text { (iii) Diet and } \\
\text { medications } \\
\text { reinforced } \\
\quad \text { Lab test: } \\
\text { (i) HbA1C } \\
\text { (ii) Fasting blood } \\
\text { glucose }\end{array}$ \\
\hline & & $\begin{array}{c}\text { Aged } 18 \text { years and } \\
\text { above }\end{array}$ & (ii) Monthly follow-ups & & $\begin{array}{l}\text { (iii) Serum } \\
\text { cholesterol } \\
\text { (iv) Weight } \\
\quad \text { Extra: } \\
\text { (i) Serum } \\
\text { creatinine, AST, } \\
\text { ALT, sodium, } \\
\text { potassium } \\
\text { Adverse events }\end{array}$ \\
\hline
\end{tabular}


TABLE 1: Continued.

\begin{tabular}{|c|c|c|c|c|c|}
\hline $\begin{array}{l}\text { Author(s), year } \\
\text { of publication, } \\
\text { study design }\end{array}$ & $\begin{array}{c}\text { Plant name and type } \\
\text { of extraction }\end{array}$ & $\begin{array}{l}\text { Country participant } \\
\text { description, no. of } \\
\text { dropouts } \\
\end{array}$ & $\begin{array}{l}\text { Duration and type of } \\
\text { treatment }\end{array}$ & Study outcome & $\begin{array}{l}\text { Brief methods, e.g., } \\
\text { blood test }\end{array}$ \\
\hline \multirow[t]{4}{*}{$\begin{array}{l}\text { Sukandar et al., } \\
2014\end{array}$} & $\begin{array}{l}\text { Curcuma longa } \\
\text { (turmeric) with } \\
\text { A. sativum L. (garlic) }\end{array}$ & Bandung, Indonesia & For 12 -week treatment: & & $\begin{array}{c}\text { Evaluated every } 2 \\
\text { weeks for } 12 \text { weeks }\end{array}$ \\
\hline & $\begin{array}{l}\text { As drug (allium } \\
\text { curcuma) in the form } \\
\text { of capsules: }\end{array}$ & $\begin{array}{c}36 \text { patients with type } 2 \\
\text { diabetes (males and } \\
\text { females) aged over } 35 \\
\text { years }\end{array}$ & (1) AC group: & $\begin{array}{l}\text { (i) Significant decrease } \\
\text { in FBG of AC group } \\
(192.76 \text { vs. } 141.71 \mathrm{mg} / \\
\text { dL) and } 2 \text { hours }\end{array}$ & $\begin{array}{l}\text { (i) Fasting blood } \\
\text { glucose }\end{array}$ \\
\hline & $\begin{array}{l}\text { (i) } 200 \mathrm{mg} \text { of turmeric } \\
\text { ethanolic extract, } \\
200 \mathrm{mg} \text { of garlic } \\
\text { aqueous extract }\end{array}$ & $\begin{array}{l}\text { (i) Random blood } \\
\text { glucose at least } \\
200 \mathrm{mg} / \mathrm{dL} \text {, fasting }\end{array}$ & $\begin{array}{l}\text { (i) } 2.4 \mathrm{~g} \text { Allium curcuma } \\
\text { capsules }\end{array}$ & $\begin{array}{l}\text { postprandial blood } \\
\text { glucose }(295.35 \mathrm{vs} \text {. } \\
204.35 \mathrm{mg} / \mathrm{dL})\end{array}$ & $\begin{array}{l}\text { (Ii) } 2 \text { hours } \\
\text { postprandial }\end{array}$ \\
\hline & Vs. & $\begin{array}{l}\text { blood glucose level at } \\
\text { least } 126 \mathrm{mg} / \mathrm{dL} \text { with }\end{array}$ & $\begin{array}{l}\text { (ii) } 2 \text { times, } 3 \text { capsules } \\
\text { per day after meal }\end{array}$ & & $\begin{array}{l}\text { (iii) Lipid profile } \\
\text { examination }\end{array}$ \\
\hline \multirow{3}{*}{$\begin{array}{l}\text { Double-blind, } \\
\text { randomized } \\
\text { control trial }\end{array}$} & Oral drug & $\begin{array}{l}\text { or without } \\
\text { dyslipidemia }\end{array}$ & $\begin{array}{l}\text { (2) Glibenclamide } \\
\text { group: }\end{array}$ & & $\begin{array}{l}\text { On week } 2 \text { and } \\
\text { week } 14 \text {, } \\
\text { examination on: }\end{array}$ \\
\hline & & 2 groups & $\begin{array}{l}\text { (iii) } 2 \text { times } 3 \text { capsules } \\
\text { per day }\end{array}$ & & \\
\hline & $\begin{array}{l}\text { (ii) } 5 \mathrm{mg} \\
\text { glibenclamide }\end{array}$ & $\begin{array}{l}\text { Glibenclamide } \\
\text { group }=12\end{array}$ & $\begin{array}{l}\text { (iv) But for morning } \\
\text { after meal, each } \\
\text { consumed } 1 \text { capsule of } \\
5 \text { mg glibenclamide, } \\
\text { and } 2 \text { capsules as } \\
\text { placebo } \\
\text { (v) Evening after meal, } \\
\text { each consumed } 2 \\
\text { placebo capsules }\end{array}$ & $\begin{array}{c}\text { (ii) Significant decrease } \\
\text { in HbAlC } 10.41 \text { vs. } \\
8.09 \text { ) }\end{array}$ & $\begin{array}{l}\text { (iv) HbA1C. } \\
\text { Fasting insulin, } \\
\text { liver function, renal } \\
\text { function, complete } \\
\text { hematology, urine } \\
\text { and heart function }\end{array}$ \\
\hline
\end{tabular}

Data extracted from each study include title, author(s), journal, year and country of publication, study characteristics (study design, study duration), characteristics of participants (gender, age, sample size), plant type and extractions, intervention (type of treatment) and control used, number of dropouts, methods, and results from the studies.

contrary, the two randomized-controlled studies used their selected medicinal plants in capsule forms, that is, existing commercial products acting as supplements, bitter melon (M. charantia), and combination extracts as Allium Curcuma of turmeric (C. longa) and garlic (A. sativum L.) in The Philippines and Indonesia, respectively.

Only the 3-month bitter melon (capsule form) study as opposed to the 14-day to 12-week studies in Indonesia on adult diabetic participants showed no significant difference in their fasting blood glucose, as well as their cholesterol level. However, consumption of rosella brewed in tea form for 14 days, as well as drug Allium Curcuma for 12 weeks, showed a significant difference in participants' fasting blood glucose for both studies, as well as 2 hours postprandially, and $\mathrm{HbAlc}$ level for the latter intervention.

\subsection{Medicinal Plants}

3.3.1. Curcuma longa (Turmeric) with Allium sativum L. (Garlic). Sukandar et al.'s study [16] consisted of 35 diabetic Indonesians and their responses to the study drug, Allium Curcuma capsule (200 mg turmeric and $200 \mathrm{mg}$ garlic) against a standard drug, $5 \mathrm{mg}$ of glibenclamide, of which the former resulted in a significant decrease in fasting and the 2-hour postprandial blood glucose. There were no changes to the participants' blood pressure, hematology profile, and liver and kidney function and no harmful drug interactions during the study.

3.3.2. Hibiscus sabdariffa L. (Roselle Plant). The quasi-experimental research study conducted by Mayasari et al. [17] was a 14-day treatment of prediabetic women (aged 30-60 years), using ready-to-brew rosella powder ( $5 \mathrm{~g}$ ) with $125 \mathrm{mg}$ stevia, and showed a significant reduction of fasting blood glucose of treatment group compared to the control group. However, there was no significant difference observed at 2-hour postprandial blood glucose results between the control and treatment group after the two-week treatment.

3.3.3. Momordica charantia (Bitter Melon). Dans et al. [18] conducted a randomized, double-blind, placebo-controlled trial testing the efficacy of $M$. charantia (bitter melon) on the control of diabetes. The primary outcome of the study was the change in $\mathrm{HbA} 1 \mathrm{c}$ level after treatment. Unlike previous nonrandomized trials on the plant, the authors of this study concluded that consumption of $M$. charantia had no effect on the HbA1c levels of the diabetic patients enrolled in the study. 


\section{Discussion}

From ancient times to the present, medicinal plants continue to play an important role in providing therapeutic assistance for various ailments and in this case for the treatment of diabetes for both developing and developed countries around the world. According to the WHO, 21000 plants around the world have been listed to provide medicinal values. Over one billion people still rely heavily on the healing properties of medicinal plants, and at least 150 plants have already been used for pharmaceutical purposes on a large scale [19].

To ensure the protection of medicinal plants from uncontrolled harvesting from their natural habitat, the WHO [20] has developed the Guidelines on Good Agricultural and Collection Practices (GACP) for Medicinal Plants. This guide aims to advise users of medicinal plants on how to practice sustainable harvesting of these plants, as well as how to carry out strategic consumption of the finished herbal products to reduce unnecessary wastage.

Hence, medicinal plant products in capsule, tea, or powdered form are more readily available commercially and easily accessible to the public for consumption as opposed to the olden days.

4.1. Turmeric (C. longa) with Garlic (A. sativum L.) and Diabetes. The well-known pungent smell of garlic is attributed to the presence of organosulfur compounds (OSCs), which are also antioxidants, antihypertensive, and antidiabetic [21, 22]. Allicin, one of the major OSCs from crushed garlic, is converted from alliin (S-allyl-cysteine sulfoxide) producing other forms of OSCs via enzymatic reactions, such as diallyl monosulfide (DAS) and oil-soluble polysulfides, diallyl disulfide (DADS), and diallyl trisulfide (DATS) [21]. These rapid reactions resulted in the abundance of OSCs for good glycemic control [22], as suggested in Figure 2(a) using aged garlic extract (adapted from Melino et al. [21]).

For almost 80 years, studies on garlic on blood glucose control have already existed. Various types of garlic preparations (such as ethanol, 40/60 petroleum ether, and diethyl ether extracts of garlic) have been tested in humans and animal studies [23]. One of the earlier studies by Jain and Vyas [24] reported a good effectiveness range of $61-93 \%$ of the various garlic extracts compared to the efficacy of a single dose of tolbutamide in alloxan diabetic rabbits. Some examples of garlic preparations include aged garlic extract, fresh garlic in tablet form, raw garlic, fresh garlic, and fermented garlic extract by Bacillus subtilis, $1.5 \%$ black garlic extract [22].

Further investigation has shown these studies favor the use of fresh garlic extraction for both animal and clinical works to measure antidiabetic properties in garlic. Wang et al. [25] reported garlic reduced fructosamine and glycosylated hemoglobin in clinical trials and was shown to provide a protective effect against diabetic retinopathy and improved blood glucose and morphological changes of retinal tissue in rats [26].
4.2. Turmeric and Diabetes. Turmeric, the root of Curcuma longa L., originates from a member of the ginger family [27], readily available in powdered form as cooking spices, food additives, and cosmetics, as well as in pharmaceutical industries [28].

Similar to garlic, the uses and health benefits of turmeric are well-researched, especially on curcuminoids, an important bioactive compound [29] that acts as a potent antioxidant, has anti-inflammatory effects, is hepatoprotective, and has antidiabetic properties [30-32]. There are three types of chemically related components of curcuminoids: curcumin (C), demethoxycurcumin (DMC), and bisdemethoxycurcumin (BDMC) [33]. Besides curcuminoids, ar-turmerone and tumerin are other types of bioactive compounds found in turmeric, which are also believed to be antidiabetic [31].

Hartogh et al. [30] recently reported that curcumin was able to improve beta-cell function, thus reducing diabetic progression amongst prediabetic and diabetic patients, whereby oral consumption of curcumin was found to be safe when taken at a dose of $6 \mathrm{~g} /$ day for 4-7 weeks [34]. Soleimani et al. [34] further reported that oral intake of curcumin is safe for human consumption at a dose of $500 \mathrm{mg}$ twice a day for 30 days. However, a recent animal study has shown that there was a possible potential risk of liver damage derived from high oral administration of curcumin at $250 \mathrm{mg} / \mathrm{kg}$ twice weekly [35]. Oral administration of turmeric extract and curcumin, however, showed protective effects on the pancreatic and renal functions of diabetic rats [35, 36]. Therefore, more studies are required to look into the safe and effective consumption of curcumin [30].

Apart from lowering the blood glucose levels, the intake of turmeric also reduces complications resulting from diabetes such as cardiovascular disease and retinal neuropathy. Srinivasan et al. conducted a three-month randomizedcontrolled trial with $C$. longa $\mathrm{L}$. which reported arterial stiffness was reduced significantly as compared with placebo in type 2 diabetes mellitus patients [37]. Banafshe et al.'s study [38] on diabetic rats has shown turmeric administration resulted in a protective effect against retinal neuropathy, overall demonstrating the protective effects of turmeric for various internal body systems.

4.3. Hibiscus sabdariffa L. and Diabetes. A woody-based subshrub, H. sabdariffa L. (roselle plant), belongs to the Malvaceae family, with more than 300 species known to be widely cultivated in both the tropical and subtropical regions of the world [39]. Traditionally and up to the present, the $H$. sabdariffa L. calyces have been used for various purposes in the food industries as well as medicinal purposes, in the form of herbal drinks and flavoring agents and as herbal medicine $[40,41]$ due to its bright red color and sour flavoring, which is mainly attributed to the high presence of anthocyanins.

Anthocyanins, a subgroup of flavonoids, have been reported to give hypoglycemic effects [42] in several studies. Sancho et al. [43] reported several experiments in vitro and in vivo have already been conducted to prove the antidiabetic properties of anthocyanins, including increased insulin 


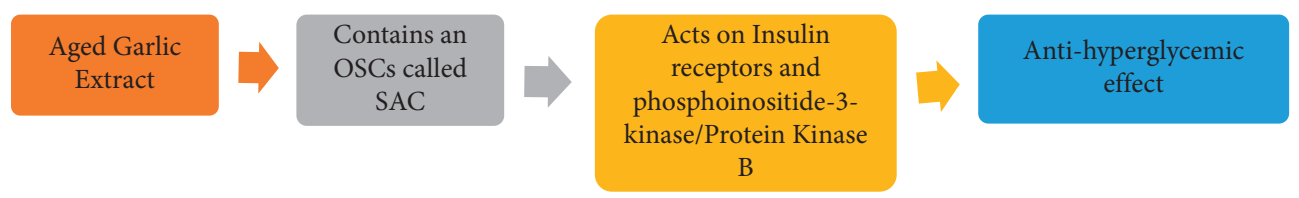

(a)

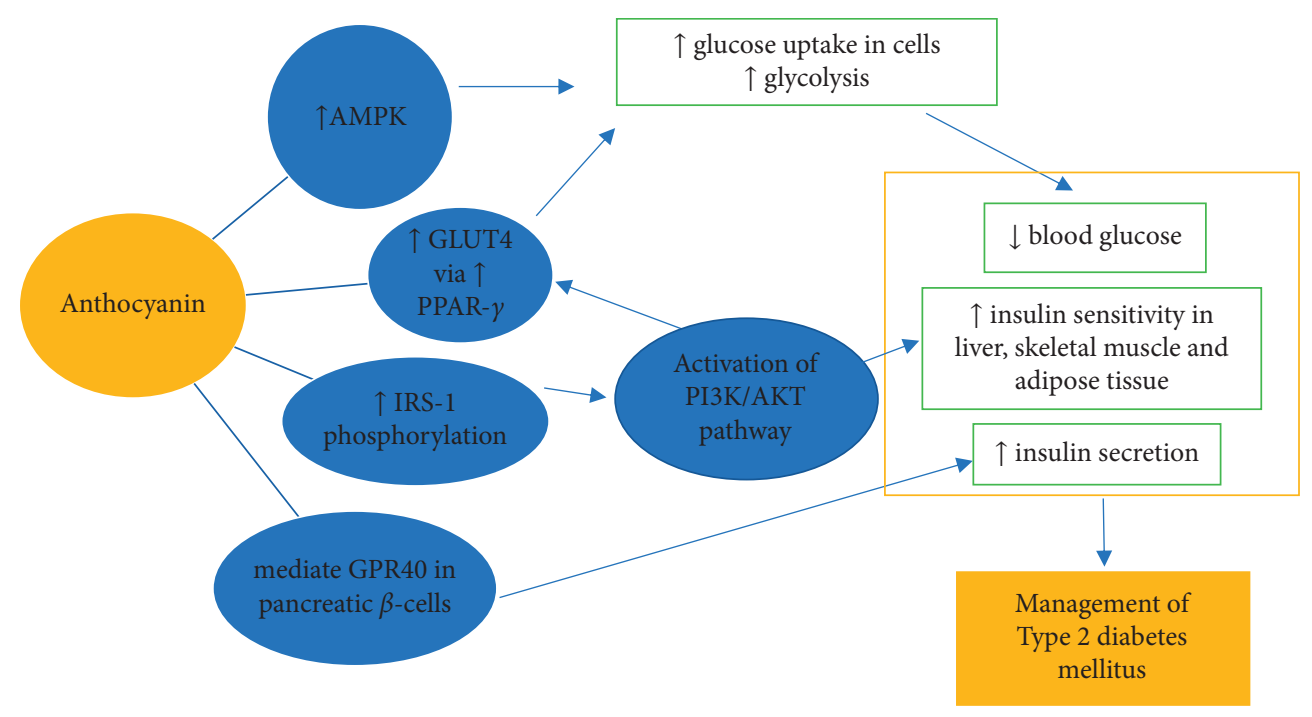

(b)

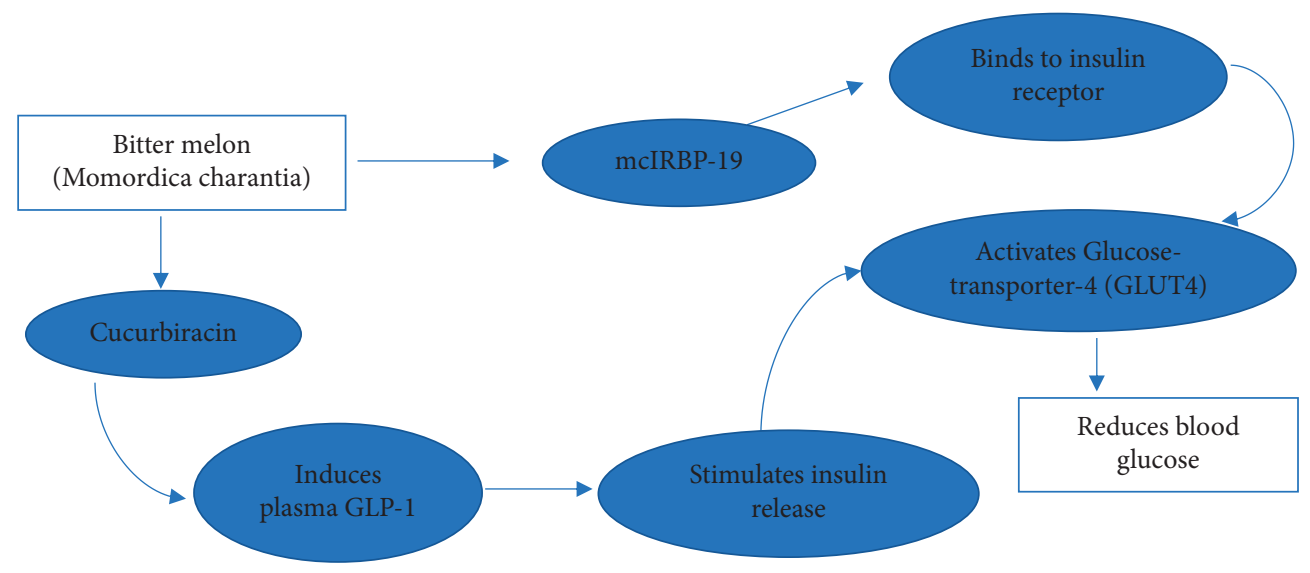

(c)

Figure 2: . Possible mechanisms of bioactive compounds. (a) Proposed mechanism in garlic, (b) proposed mechanism of anthocyanin in rosella plant, and (c) proposed mechanism in bitter melon to manage hyperglycaemia.

secretion, improved insulin resistance, and lowered blood glucose, as also shown in several animal studies [44-46] using different breeds of rats and duration of intervention.

Mayasari et al.'s study [17] showed that a 14-day intervention using rosella-stevia tea resulted in a significant reduction in the fasting blood glucose of prediabetic women, attributed by the active compounds present, which may be due to not only the high antioxidant properties of $H$. sabdariffa L. but potentially also enzymatic inhibition and other pathways.

Using the High-Performance Liquid Chromatography (HPLC) and Liquid Chromatography-Mass Spectrometry (LCMS) [47], comparisons were made using various solvents to identify the maximum extraction of the bioactive compounds, which are predominantly delphinidin, cyanidin 3-sambubioside, and cyanidin 3-glucoside [41]. The highest amount of anthocyanins was extracted in water as opposed to using solvents such as methanol, ethyl acetate, and hexane in the presence/absence of formic acid, with different extraction times and temperatures [47]. Hence, the study concluded that the maximum extractable compounds and yields of anthocyanins are in an aqueous solution, for 10 minutes at 100 degrees Celsius. These results were further explained through the nature of the identified anthocyanins' structures, that is, having high hydrogen-donating capacity; hence, maximum extractions are highly dependent on the polarity of the solvent, with water being the highest compared to the rest of the mentioned solvents [48-50]. 
Therefore, Mayasari et al.'s positive results [17] can be justified due to the scientific evidence presented in in vitro and in vivo studies, whereby participants were given strict instructions on the correct tea preparation method before consumption, that is, $5 \mathrm{~g}$ of rosella powder with $125 \mathrm{~g}$ of stevia in boiling water for 5 minutes.

Although the mechanisms and pathways of anthocyanins of $H$. sabdariffa L. are not completely clear, Peng et al. [45] attributed the reduction in blood glucose and improved insulin sensitivity to the mediation of GPR40 in pancreatic beta-cells and the insulin receptor substrate- 1 serine kinase that regulates the insulin receptor signal pathway. The improvement was shown in the number of pancreatic $\beta$ cells and reduction in blood glucose level in streptozotocin-induced diabetic rats [51]; it also showed no correlation was observed between the level of serum insulin and lowering of blood glucose, indicating presence of insulin resistance in type 2 diabetic rats group. One study using mulberry anthocyanin extract reported reduced fasting blood glucose and serum insulin in $\mathrm{db} / \mathrm{db}$ mice, whereby in vitro further investigation showed the activation of $\mathrm{PI} 3 \mathrm{~K} / \mathrm{AKT}$ pathways in HepG2 cells that improves insulin resistance and increased glucose consumption, glucose uptake, and glycogen content [52].

Hence, the possible mechanism of anthocyanins on glucose metabolism is proposed to affect insulin secretion and improve insulin sensitivity and glucose uptake in the liver, adipose tissues, and skeletal muscles (Figure 2(b)) to lower blood glucose, via GPR40, AMPK, GLUT4 AMD PI3K/AKT pathways.

Further investigation needs to be done to understand the mechanisms associated with improved insulin production, sensitivity, and reduced serum blood glucose.

4.4. Momordica charantia and Diabetes. M. charantia is one of the most frequently ingested herbs for the control of diabetes in complementary and alternative medicine users in Malaysia and India, as well as users of traditional Chinese medicine [53-55]. Bioactive compounds that have been identified within the plant include charantin, an insulin-like peptide, cucurbitane glycosides, momordicin, and oleanolic acids [56, 57]. Both animal and human studies have suggested that the active compounds within the plant can exert hypoglycemic effects [58, 59]. However, no hypoglycemic effect was identified by Dans et al. [18], which was the only study available on $M$. charantia found in this systematic review.

Both Dans et al. [18] and Cortez-Navarette et al. [58] carried out randomized-controlled trials (RCTs). However, different bioactive compounds have been identified in $M$. charantia extracts collected from different regions in China [55]. The differing results obtained by the two RCTs may therefore be due to the different compounds available in the M. charantia plants in the Philippines and Mexico.

Despite the negative results reported by Dans et al. [18], they suggested a study with a bigger test population may be able to detect more modest effects on blood glucose. It has recently been reported that lactic acid fermented $M$. charantia juice lowered fasting and postprandial blood glucose levels in rats more efficiently than nonfermented $M$. charantia juice [60]. Therefore, it may be useful to use a similar fermented juice in human trials as well, in order to accentuate the antidiabetic effects of the plant which may have been masked in the Dans study [18]. Another avenue of research that seems promising is the use of a bitter melon peptide mcIRBP-19 in controlling blood glucose levels in diabetic patients, as this may give a more concentrated dose of antidiabetic bioactive compounds to the patients [61]. However, it should be noted that M. charantia was shown to have developmental toxicity on zebrafish embryos, so it should be taken with caution, particularly by those who are or planning to be pregnant [62].

Figure 2(c) illustrates possible mechanisms involved in M. charantia of cucurbitacin and mcIRBP-19 which activates GLUT4 to increase glucose uptake into cells to lower blood glucose and assist in the management of diabetes.

\section{Conclusion}

This review demonstrates the limitations in published articles on human clinical trials for medicinal plants' intervention for diabetes. Upon further investigations on the four identified medicinal plants that were mostly done in animal studies, findings showed positive effects in the management of diabetes, such as hyperglycemia. The varying methods and extractions used on different medicinal plants in different parts of the world are also worth noting, which is likely attributed to the inconsistencies in data results. The most used and reliable extractions of medicinal plants are the powdered form, which are then to be diluted in either aqueous or alcoholic solutions prior to intervention, especially in animal studies. Hence, further testing and standardization of the methods in the studies can be suggested for human clinical trials for reliable data collections such as methods of extract preparation, duration of intervention, and conditions set for the study design.

\section{Data Availability}

No data were used to support the findings of this study.

\section{Conflicts of Interest}

The authors declare that they have no conflicts of interest.

\section{Authors' Contributions}

NHS, SRA, and INZ conceived and designed the study, interpreted and analyzed the data, and prepared the original draft. NHS performed data extraction. All authors provided critical revisions of the manuscript. All authors approved the final version of the manuscript.

\section{Acknowledgments}

The authors thank Dr. Lin Naing (Professor in Biostatistics at the PAPRSB Institute of Health Sciences, University Brunei Darussalam) for providing comprehensive feedback and insightful comments on the overall structure of this paper. This work was supported and funded by Universiti 
Brunei Darussalam's Herbal Research Grant, UBD/RSCH/ URC/NIG/1.0/2020/007, Dr. Siti Rohaiza Ahmad (PI).

\section{References}

[1] S. Cousins, "Addressing Asia's fast growing diabetes epidemic," Bulletin of the World Health Organization, vol. 95, no. 8, pp. 550-551, 2017.

[2] IDF, International Diabetes Federation-Facts and figures, IDF Diabetes Atlas, Brussels, Belgium, 9th Edition, 2019.

[3] S. Bolen, L. Feldman, J. Vassy et al., "Systematic review: comparative effectiveness and safety of oral medications for type 2 diabetes mellitus," Annals of Internal Medicine, vol. 147, no. 6, pp. 386-399, 2007.

[4] O. Tabatabaei-Malazy, A. Ramezani, R. Atlasi, B. Larijani, and M. Abdollahi, "Scientometric study of academic publications on antioxidative herbal medicines in type 2 diabetes mellitus," Journal of Diabetes and Metabolic Disorders, vol. 15, no. 1, p. $48,2016$.

[5] M. K. Lim, P. Sadarangani, H. L. Chan, and J. Y. Heng, "Complementary and alternative medicine use in multiracial Singapore," Complementary Therapies in Medicine, vol. 13, no. 1, pp. 16-24, 2005.

[6] B. B. Petrovska, "Historical review of medicinal plants' usage," Pharmacognosy Reviews, vol. 6, 2012.

[7] M. Ekor, "The growing use of herbal medicines: issues relating to adverse reactions and challenges in monitoring safety," Frontiers in Neurology, vol. 4, 2014.

[8] G. Di Fabio, V. Romanucci, M. Zarrelli, M. Giordano, and A. Zarrelli, "C-4 gem-dimethylated oleanes of Gymnema sylvestre and their pharmacological activities," Molecules, vol. 18, no. 12, pp. 14892-14919, 2013.

[9] A. G. Atanasov, B. Waltenberger, E.-M. Pferschy-Wenzig et al., "Discovery and resupply of pharmacologically active plant-derived natural products: a review," Biotechnology Advances, vol. 33, no. 8, pp. 1582-1614, 2015.

[10] H. Yuan, Q. Ma, L. Ye, and G. Piao, "The traditional medicine and modern medicine from natural products," Molecules, vol. 21, no. 5, p. 559, 2016.

[11] M. Saxena, J. Saxena, R. Nema, D. Singh, and A. Gupta, "Phytochemistry of medicinal plants," J Pharmacogn Phytochem [Internet], vol. 1, no. 6, pp. 168-182, 2013.

[12] G. Fabio, V. Romanucci, C. Marino, A. Pisanti, and A. Zarrelli, "Gymnema sylvestre R. Br., an Indian medicinal herb: traditional uses, chemical composition, and biological activity," Current Pharmaceutical Biotechnology, vol. 16, no. 6, pp. 506-516, 2015.

[13] W. Kooti, M. Farokhipour, Z. Asadzadeh, D. Ashtary-Larky, and M. Asadi-Samani, "The role of medicinal plants in the treatment of diabetes: a systematic review," Electronic Physician, vol. 8, 2016.

[14] ASEAN, ASEAN Herbal and Medicinal Plants Volume 2, M. Mohtar, L. S. Kiong, U. H. Badron, and R. Mat Ali, Eds., , ASEAN Secretariat, Jakarta, Indonesia, Second edition435 pages, ASEAN Secretariat, Jakarta, Indonesia, 2017.

[15] S. R. O’Connor, M. A. Tully, B. Ryan, J. M. Bradley, G. D. Baxter, and S. M. McDonough, "Failure of a numerical quality assessment scale to identify potential risk of bias in a systematic review: a comparison study," BMC Research Notes, vol. 8, 2015.

[16] E. Y. Sukandar, P. Sudjana, I. K. Adnyana, A. S. Setiawan, and U. Yuniarni, "Recent study of turmeric in combination with garlic as antidiabetic agent," Procedia Chemistry, vol. 13, pp. 44-56, 2014.

[17] N. R. Mayasari, S. Susetyowati, M. S. H. Wahyuningsih, and P. Probosuseno, "Antidiabetic effect of rosella-stevia tea on prediabetic women in Yogyakarta, Indonesia," Journal of the American College of Nutrition, vol. 37, no. 5, pp. 373-379, 2018.

[18] A. M. L. Dans, M. V. C. Villarruz, C. A. Jimeno et al., "The effect of Momordica charantia capsule preparation on glycemic control in Type 2 diabetes mellitus needs further studies," Journal of Clinical Epidemiology, vol. 60, no. 6, pp. 554-559, 2007.

[19] P. C. Trivedi, Medicinal Plants: Traditional Knowledge, P. C. Trivedi, Ed., p. 272, India: I.K. International Publishing House Pvt Ltd, New Delhi, India, 2008.

[20] WHO, WHO Guidelines on Good Agricultural and Collection Practices (GACP) for Medicinal Plants, WHO. World Health Organization, Geneva, Switzerland, 2015.

[21] S. Melino, S. Leo, and V. T. Papajani, "Natural hydrogen sulfide donors from Allium sp. as a nutraceutical approach in type 2 diabetes prevention and therapy," Nutrients, vol. 11, 2019.

[22] A. Shang, S. Y. Cao, X. Y. Xu et al., "Bioactive compounds and biological functions of garlic (Allium sativum L.)," Foods, vol. 8, 2019.

[23] K. Srinivasan, "Plant foods in the management of diabetes mellitus: spices as beneficial antidiabetic food adjuncts," International Journal of Food Sciences and Nutrition, vol. 56, 2005.

[24] R. C. Jain and C. R. Vyas, "Garlic in alloxan-induced diabetic rabbits," American Journal of Clinical Nutrition, vol. 28, no. 7, pp. 684-685, 1975.

[25] J. Wang, X. Zhang, H. Lan, and W. Wang, "Effect of garlic supplement in the management of type 2 diabetes mellitus (T2DM): a meta-analysis of randomized controlled trials," Food and Nutrition Research, vol. 61, no. 1, Article ID 1377571, 2017.

[26] A. Y. Al-brakati, "Protective effect of garlic against diabetic retinopathy in adult albino rats," Research Journal of Pharmaceutical, Biological and Chemical Sciences, vol. 7, no. 5, pp. 2748-2759, 2016.

[27] F. Pivari, A. Mingione, C. Brasacchio, and L. Soldati, "Curcumin and type 2 diabetes mellitus: prevention and treatment," Nutrients, vol. 11, no. 8, Article ID 1837, 2019.

[28] E. Hay, A. Lucariello, M. Contieri et al., "Therapeutic effects of turmeric in several diseases: an overview," Chemico-Biological Interactions, vol. 310, no. 1, Article ID 108729, 2019.

[29] V. S. R. Kotra, L. Satyabanta, and T. K. Goswami, “A critical review of analytical methods for determination of curcuminoids in turmeric," Journal of Food Science and Technology, vol. 56, 2019.

[30] D. J. Den Hartogh, A. Gabriel, and E. Tsiani, "Antidiabetic properties of curcumin II: evidence from in vivo studies," Nutrients, vol. 12, no. 1, p. 58, 2019.

[31] A. S. P. Pereira, A. J. Banegas-Luna, J. Peña-García, H. PérezSánchez, and Z. Apostolides, "Evaluation of the anti-diabetic activity of some common herbs and spices: providing new insights with inverse virtual screening," Molecules, vol. 24, no. 22, p. 4030, 2019.

[32] S. R. Ahmad, "Foods consumed with rice that elicit a reduction in glucose response among healthy individuals," Current Research in Nutrition and Food Science, vol. 8, 2020.

[33] F.-C. Meng, Y.-Q. Zhou, D. Ren et al., "Turmeric: a review of its chemical composition, quality control, bioactivity, and 
pharmaceutical application," in Natural and Artificial Flavoring Agents and Food Dyes, pp. 299-350, Elsevier, Amsterdam, Netherlands, 2018.

[34] V. Soleimani, A. Sahebkar, and H. Hosseinzadeh, "Turmeric (Curcuma longa) and its major constituent (curcumin) as nontoxic and safe substances: review," Phytotherapy Research, vol. 32, 2018.

[35] R. Essa, A. M. El Sadek, M. E. Baset et al., "Effects of Turmeric (Curcuma longa) Extract in streptozocin-induced diabetic model," Journal of Food Biochemistry, vol. 43, 2019.

[36] S. Sharma, S. K. Kulkarni, and K. Chopra, "Curcumin, the active principle of turmeric (Curcuma longa), ameliorates diabetic nephropathy in rats," Clinical and Experimental Pharmacology and Physiology, vol. 33, 2006.

[37] A. Srinivasan, S. Selvarajan, S. Kamalanathan, T. Kadhiravan, N. C. Prasanna Lakshmi, and S. Adithan, "Effect of Curcuma longa on vascular function in native Tamilians with type 2 diabetes mellitus: a randomized, double-blind, parallel arm, placebo-controlled trial," Phytotherapy Research: PT, vol. 33, no. 7, pp. 1898-1911, 2019.

[38] H. R. Banafshe, G. A. Hamidi, M. Noureddini, S. M. Mirhashemi, R. Mokhtari, and M. Shoferpour, "Effect of curcumin on diabetic peripheral neuropathic pain: possible involvement of opioid system," European Journal of Pharmacology, vol. 723, 2014.

[39] M. L. Wang, B. Morris, B. Tonnis, J. Davis, and G. A. Pederson, "Assessment of oil content and fatty acid composition variability in two economically important Hibiscus species," Journal of Agricultural and Food Chemistry, vol. 60, no. 26, pp. 6620-6626, 2012.

[40] I. Da-Costa-Rocha, B. Bonnlaender, H. Sievers, I. Pischel, and M. Heinrich, "Hibiscus sabdariffa L. - A phytochemical and pharmacological review," Food Chemistry, vol. 165, pp. 42443, 2014.

[41] B. H. Ali, N. Al Wabel, and G. Blunden, "Phytochemical, pharmacological and toxicological aspects of Hibiscus sabdariffa L.: a review," Phytotherapy Research, vol. 19, 2005.

[42] R. Mohamed, J. Fernández, M. Pineda, and M. Aguilar, "Roselle (Hibiscus sabdariffa) seed oil is a rich source of $\gamma$-tocopherol," Journal of Food Science, vol. 72, 2007.

[43] R. A. S. Sancho and G. M. Pastore, "Evaluation of the effects of anthocyanins in type 2 diabetes," Food Research International, vol. 46, no. 1, pp. 378-386, 2012.

[44] A. H. Nazratun Nafizah, S. B. Budin, A. H. Zaryantey et al., "Aqueous calyxes extract of Roselle or Hibiscus sabdariffa Linn supplementation improves liver morphology in streptozotocin induced diabetic rats," Arab Journal of Gastroenterology, vol. 18, no. 1, pp. 13-20, 2017.

[45] C.-H. Peng, C.-C. Chyau, K.-C. Chan, T.-H. Chan, C.-J. Wang, and C.-N. Huang, "Hibiscus sabdariffa polyphenolic extract inhibits hyperglycemia, hyperlipidemia, and glycation-oxidative stress while improving insulin resistance," Journal of Agricultural and Food Chemistry, vol. 59, no. 18, pp. 9901-9909, 2011.

[46] F. Agoreyo, B. Agoreyo, and M. Onuorah, "Effect of aqueous extracts of Hibiscus sabdariffa and Zingiber Officinale on blood cholesterol and glucose levels of rats," African Journal of Biotechnology, vol. 7, no. 21, 2008.

[47] H. A. Sindi, L. J. Marshall, and M. R. A. Morgan, "Comparative chemical and biochemical analysis of extracts of Hibiscus sabdariffa," Food Chemistry, vol. 164, pp. 23-29, 2014.

[48] L. R. Fukumoto and G. Mazza, "Assessing antioxidant and prooxidant activities of phenolic compounds $\dagger$," Journal of
Agricultural and Food Chemistry, vol. 48, no. 8, pp. 35973604, 2000.

[49] B. V. Ramakrishna, G. K. Jayaprakasha, B. S. Jena, and R. P. Singh, "Antioxidant activities of roselle (Hibiscus sabdariffa) calyces and fruit extracts," Journal of Food Science and Technology, vol. 45, no. 3, pp. 223-227, 2008.

[50] N. Mohd-Esa, F. S. Hern, A. Ismail, and C. L. Yee, "Antioxidant activity in different parts of roselle (Hibiscus sabdariffa L.) extracts and potential exploitation of the seeds," Food Chemistry, vol. 122, no. 4, pp. 1055-1060, 2010.

[51] Z. F. R. Mardiah, F. R. Zakaria, E. Prangdimurti, and R. Damanik, "Anti-inflammatory of purple roselle extract in diabetic rats induced by streptozotocin," Procedia Food Science, vol. 3, pp. 182-189, 2015.

[52] F. Yan, G. Dai, and X. Zheng, "Mulberry anthocyanin extract ameliorates insulin resistance by regulating PI3K/AKT pathway in HepG2 cells and db/db mice," The Journal of Nutritional Biochemistry, vol. 36, pp. 68-80, 2016 Oct.

[53] S. M. Ching, Z. A. Zakaria, F. Paimin, and M. Jalalian, "Complementary alternative medicine use among patients with type 2 diabetes mellitus in the primary care setting: a cross-sectional study in Malaysia," BMC Complementary and Alternative Medicine, vol. 13, 2013.

[54] S. Dixit and S. Tiwari, "Investigation of anti-diabetic plants used among the ethnic communities of Kanpur division, India," Journal of Ethnopharmacology, vol. 253, 2020.

[55] S. Zhou, P. M. Allard, C. Wolfrum, C. Ke, C. Tang, Y. Ye et al., "Identification of chemotypes in bitter melon by metabolomics: a plant with potential benefit for management of diabetes in traditional Chinese medicine," Metabolomics, vol. 15, 2019.

[56] M.-J. Tan, J.-M. Ye, N. Turner et al., “Antidiabetic activities of triterpenoids isolated from bitter melon associated with activation of the AMPK pathway," Chemistry and Biology, vol. 15, no. 3, pp. 263-273, 2008.

[57] C. M. Wong, T. B. Ng, and H. W. Yeung, "Screening of Trichosanthes kirilowii, Momordica charantia and Cucurbit a maxima (family cucurbitaceae) for compounds with antilipolytic activity," Journal of Ethnopharmacology, vol. 13, no. 3, pp. 313-321, 1985.

[58] M. Cortez-Navarrete, E. Martínez-Abundis, K. G. PérezRubio, M. González-Ortiz, and M. Méndez-Del Villar, "Momordica charantia administration improves insulin secretion in type 2 diabetes mellitus," Journal of Medicinal Food, vol. 21, 2018.

[59] Y. Srivastava, H. Venkatakrishna-Bhatt, Y. Verma, K. Venkaiah, and B. H. Raval, "Antidiabetic and adaptogenic properties ofMomordica charantia extract: an experimental and clinical evaluation," Phytotherapy Research, vol. 7, no. 4, pp. 285-289, 1993.

[60] L. Hartajanie, S. Fatimah-Muis, K. Heri-Nugroho Hs, I. Riwanto, and M. Sulchan, "Probiotics fermented bitter melon juice as promising complementary agent for diabetes type 2: study on animal model," Journal of Nutrition and Metabolism, vol. 2020, Article ID 6369873, 7 pages, 2020.

[61] P. K. Hsu, F. F. C. Pan, and H. C. Sen, "McIRBP-19 of bitter melon peptide effectively regulates diabetes mellitus(DM) patients' blood sugar levels," Nutrients, vol. 12, 2020.

[62] M. F. Khan, N. Abutaha, F. A. Nasr, A. S. Alqahtani, O. M. Noman, and M. A. M. Wadaan, "Bitter gourd (Momordica charantia) possess developmental toxicity as revealed by screening the seeds and fruit extracts in zebrafish embryos," BMC Complementary and Alternative Medicine, vol. 19, 2019. 